UDC 537.877

\author{
A. Schekotov ${ }^{1}$, E. Fedorov ${ }^{1}$, Y. Hobara ${ }^{2,3,4}$, M. Hayakawa ${ }^{3,5,6,7}$ \\ ${ }^{1}$ Institute of Physics of the Earth, Russian Academy of Sciences, 10, Bolshaya Gruzinskaya, 124995, Moscow, \\ Russia \\ ${ }^{2}$ University of Electro-Communications(UEC), Graduate School of Informatics and Engineering, \\ 1-5-1 Chofugaoka,Chofu Tokyo 182-8585, Japan \\ ${ }^{3}$ UEC, Research Station on Seismo Electromagnetics, Chofu Tokyo, Japan \\ ${ }^{4} U E C$, Research Center of Space Physics and Radio Engineering, Chofu Tokyo, Japan \\ ${ }^{5}$ UEC, Advanced Wireless Communications research Center, Chofu Tokyo, Japan \\ ${ }^{6}$ Hayakawa Institute of Seismo Electromagnetics, Co.Ltd., UEC Incubation Center, Chofu Tokyo, Japan \\ ${ }^{7}$ Earthquake Analysis Laboratory, Information Systems Inc., Kita-aoyama 2-12-42-305, \\ Minato-ku Tokyo 107-0061, Japan
}

\title{
ULF MAGNETIC FIELD DEPRESSION AS A POSSIBLE PRECURSOR TO THE 2011/3.11 JAPAN EARTHQUAKE
}

\begin{abstract}
The depression (reduction in amplitude) of ULF magnetic field variations of magnetospheric origin is studied at various distances from the epicenter of the strongest earthquake (EQ), which occurred in Japan on March 11, 2011. For this purpose, we have used the ULF data in Japan recorded by fluxgate magnetometers at three places located at distances of $\sim 300 \mathrm{~km}$ to $\sim 1300 \mathrm{~km}$ from the epicenter of the main shock. The period of data analysis is from December 1, 2010 to May 31, 2011. We have found a sharp depression of the horizontal ULF magnetic field component at the frequency of $0.03 \ldots 0.05 \mathrm{~Hz}(30 \ldots 50 \mathrm{mHz})$ at all of three Japanese observatories (Kakioka, Memambetsu and Kanoya) three days before the first strong foreshock $\left(M_{w}=7.5\right)$ and five days before the main shock $\left(M_{w}=9\right)$. This maximum depression is found to be several times greater than all previous deviations, but the depression seems to be most enhanced at Kakioka, the station nearest to the EQ epicenter. So that it is likely that this phenomenon could be a possible precursor to the huge 3.11 EQ.

Key words: earthquakes (EQs), short-term precursors, ULF magnetic field depression, seismo-ionospheric depression, seismoelectromagnetics
\end{abstract}

The idea was recently spelled based on the extensive studies during the last few decades that electromagnetic phenomena appear prior to an earthquake (EQ) [1-3]. These are the lithospheric phenomena such as geoelectric field, ULF (ultra-lowfrequency, frequency less than $10 \mathrm{~Hz}$, but mainly in the $\mathrm{mHz}$ range) electromagnetic emissions, etc., and seismo-atmospheric and - ionospheric perturbations. The most convincing effect at the moment is the ionospheric perturbation detected by the subionospheric VLF/LF propagation: a significant statistical correlation has been established between the ionospheric perturbations and the EQs with magnitude greater than 6.0 and with depth smaller than $40 \mathrm{~km}[4]$.

Among the lithospheric effects, the ULF electromagnetic emissions are found to be promising for the EQ prediction, though the number of events is not so abundant as compared with the ionospheric perturbations mentioned above [5-7]. For the first time, the ULF radiation was observed for the Spitak EQ in 1988 [8-10]. An evidence of ULF signature was found of the 1989 Loma Prieta EQ $\left(M_{s}=7.2\right)$. In the case of the 1993 Guam EQ $(M=8.0)$ the ULF emissions were also found [11]. The ULF studies were summarized in $[3,5,12]$, though recently there have been published few papers casting a doubt to the presence of seismogenic ULF emissions [13, 14].

A new type of ULF anomaly in EQ effects has been found $[15,16]$. Being completely different from the seismogenic lithospheric ULF emissions mentioned above, this new effect is observed in the form of a depression in the amplitude of ULF magnetic field fluctuations (generated in the magnetosphere) a few days before an EQ. An extensive study of this effect have been performed on the basis of observations in Russia (Karymshiro) during the four-year period of June 21, 2000 through June 6, 2004 and those in Japan (Matsukawa) during the two-year period from October 22, 2001 to October 26,2003 [16]. Their result was based on the analyses of 38 EQs with magnitude in a range from 4.5 to 7.0 in Russia and of 22 separate EQs with magnitude from 5.5 to 8.3 in Japan. The basic properties of depression of magnetospheric ULF fluctuations were statistically confirmed, and are summarized as follows [3].

- The noticeable ULF depression occurs 1-5 days before a separate EQ or a sharp growth of seismicity. It appears in the vicinity of the local midnight and is observed only during 1-2 nights. This phenomenon has a random character during the period of prolonged seismic activity (for example, during a swarm), which cannot be used for the EQ prediction in these intervals. It cannot be used either as a precursor of successive events with an interval smaller than one-two weeks.

- The ULF reduction is especially noticeable in the horizontal magnetic field components in the frequency band $\sim 0.03 \ldots 0.05 \mathrm{~Hz}(30 \ldots 50 \mathrm{mHz})$.

- The magnitude of ULF depression is linearly dependent on the seismic energy release of the forthcoming EQ at the observation point. 
- This phenomenon has the properties of locality and stationarity.

In this paper we examine the ULF depression effect for the case of the recent violent Japan EQ $\left(M_{w}=9\right)$ happened on March 11, 2011, as a case study. Initially we show the presence of clear depressions in the horizontal component of magnetospheric ULF fluctuations on March 6, 2011, and then we discuss the features of this anomaly as a possible precursor to this huge EQ.

1. ULF data used and analysis period. One of the main problems in doing this work was to find the desired data. We found them at the site of the World Data Center for Geomagnetism, Kyoto (WDC for Geomagnetism). The data from the WDC are given in the format of IAGA (International Association of Geomagnetism and Aeronomy) 2000, where the magnetic field is represented by four components: Horizontal $(\mathrm{H})$, declination $(\mathrm{D})$, vertical $(\mathrm{Z})$ and total field $(\mathrm{F})$. The period of data analysis is 6 months from December 1, 2000 to May 31, 2011.

The data are available from three magnetic observatories; Memabetsu (abbreviated as MMB in the following), Kakioka (KAK) and Kanoya (KNY) shown as black diamonds in Fig. 1.

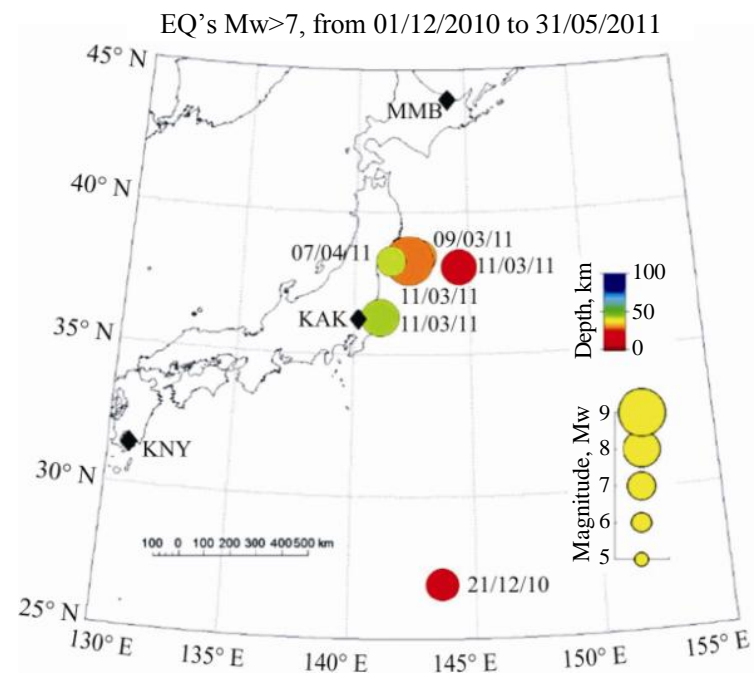

Fig. 1. Relative location of three Japanese ULF observatories (KAK, MMB and KNY) and most powerful $\left(M_{w}>7\right)$ EQs which occurred from December 1, 2010 to May 31, 2011. Our target EQ took place on March 11, 2011. Each circle corresponds to one particular EQ: the center of the circle is the EQ epicenter and its color indicates the depth

The sampling frequency (Fs) of magnetometers at all these stations is equal to $1 \mathrm{~Hz}$. The positions and magnitudes of EQs with $M_{w}>7$ and with depth smaller than $100 \mathrm{~km}$, are also indicated as circles in the same figure. The center of a circle indicates the EQ epicenter. Its size is proportional to EQ magnitude, and the color refers to the depth. We have used the seismic data from the ANSS Worldwide Earthquake Catalog. The main shock took place at 14:46:18 LT (local time) on March 11, 2011 with its epicenter at the geographic coordinates $\left(36^{\circ} 06^{\prime} \mathrm{N}, 142^{\circ} 52^{\prime} \mathrm{E}\right)$ as shown in Fig. 1 . The magnitude was $M_{w}=9$ and the depth was about $20 \mathrm{~km}$. This EQ is a typical oceanic EQ of the plate type, being different from the extensively-studied faulttype EQs such as the Kobe EQ. The distance of each magnetic observatory from the epicenter of the main shock was $640 \mathrm{~km}$ for MMB, $300 \mathrm{~km}$ for $\mathrm{KAK}$, and $1300 \mathrm{~km}$ for KNY, respectively.

In the following sections we present the data processing procedure, the analysis results, and summary and discussions.

2. Data analysis. Following the main characteristic of our target phenomenon summarized in Introduction, we are interested in the behavior of the horizontal $\mathrm{H}$ magnetic field component of magnetospheric ULF fluctuations. As was already noted in Introduction, the maximum of depression in the horizontal component is usually observed in the immediate vicinity of the local midnight. However, the decrease in signal level around the local midnight is primarily caused by the decrease in the industrial interference. So the intervals of data analysis should be chosen carefully, in such a way that all the observatories are situated at the same LT. We have to think of the LT intervals with low level of electromagnetic man-made noise (e.g., trains, electric motors, other similar equipments, etc.) and we choose the LT close to local midnight. The optimum time is found to lie in the vicinity of $T_{l}=3 h \mathrm{LT}$ or $T_{l}=(24 h-L o n / 15)+3 h \mathrm{UT}$ for each site as based on our previous measurements [16], where Lon is the geographic longitude of a ULF observatory.

The value of absolute depression Dep in the horizontal component of magnetospheric ULF variations is calculated as,

$$
\text { Dep }=\frac{1}{\left\langle U^{2}\right\rangle_{\Delta T}}
$$

where we have the squared output signal $U$ in the denominator observed by the sensor in the frequency band of $\Delta F=0.03 \ldots 0.05 \mathrm{~Hz}$ averaged in the interval $\Delta T=3 h \pm 2 h$ LT. The following value was adopted as a measure for the relative depression (further, depression) of the $\mathrm{i}$-th date

$$
\delta \operatorname{Dep}_{i}=\frac{\operatorname{Dep}_{i}-\frac{1}{N} \sum_{j=i-N}^{j=i-1} \operatorname{Dep}_{i}}{\frac{1}{N} \sum_{j=i-N}^{j=i-1} \operatorname{Dep}_{i}} .
$$

Here $N$ is the number of preceding days for averaging. In the present study $N=5$. All the 
parameters in (2), i. e. $N, \Delta T$ and $\Delta F$ are chosen to maximize the success of forecast.

The term "the success of forecast" means that a precursor exceeds a certain threshold and provides a sufficient reliability of the forecast. Realibility of the forecast can be estimated by the method described in [17], when the value of probability gain (PG) is used as a criterion of the reliability. The PG depends on the statistics of detection (success rate, alarm rate), the total interval of observations, and the alarm interval of the precursor (5 days in the case of our ULF depression). Then, the precursor is considered to be reliable if $P G>1$. It is possible to find the maximum value of PG by changing the threshold level, but this procedure is possible only for the sufficient statistics.

Further comments on the parameters $(N, \Delta T$, and $\Delta F$ ) in (2) are given one by one.

First, as for the number of averaging days $N$. In order to detect an impulsive signal (depression) effectively, we should reduce influence of the longterm variations of the ULF depressions caused by changes of the background seismicity or the longterm variation of the magnetic fields. Actually, $\delta D e p$ of (2) works as a high-pass filter with the cutoff frequency $\sim 1 / N$. The parameter, $N$ was chosen by changing its value in such a way that to obtain a higher ratio of the particular precursor to the background value for the previous remarkable EQ of December 21, 2010.

The optimal time window $\Delta T$ was estimated in our previous study being in the vicinity of local midnight. Unfortunately, this choice is impossible in Japan strongly contaminated by the industrial interference. So, the time window was shifted to $3 h$ in the morning. We have used the same time window $(\Delta T=3 h \pm 2 h \mathrm{LT})$ for all magnetometers, which gives us a possibility to obtain the response suitable for a comparison of results at all three observatories. However, the magnetometer at Kakioka had smaller "sensitivity" to the depression due to higher interference.

The last parameter of the frequency window $\Delta F$ was chosen from our previous results, which indicated the maximal depression at $30 \ldots 50 \mathrm{mHz}$ frequencies before an $\mathrm{EQ}$. We have tested the correctness of the choice by using the same remarkable EQ with $M_{w}=7.4$ on December 21, 2010 shown in Fig. 1.

3. Results of analysis. The main result on the depression of ULF magnetic field component is summarized in Fig. 2. The top panel indicates the temporal evolutions of Dst index as a measure of the geomagnetic activity (blue line) and the occurrence of EQs with magnitudes $M_{w}>5$.

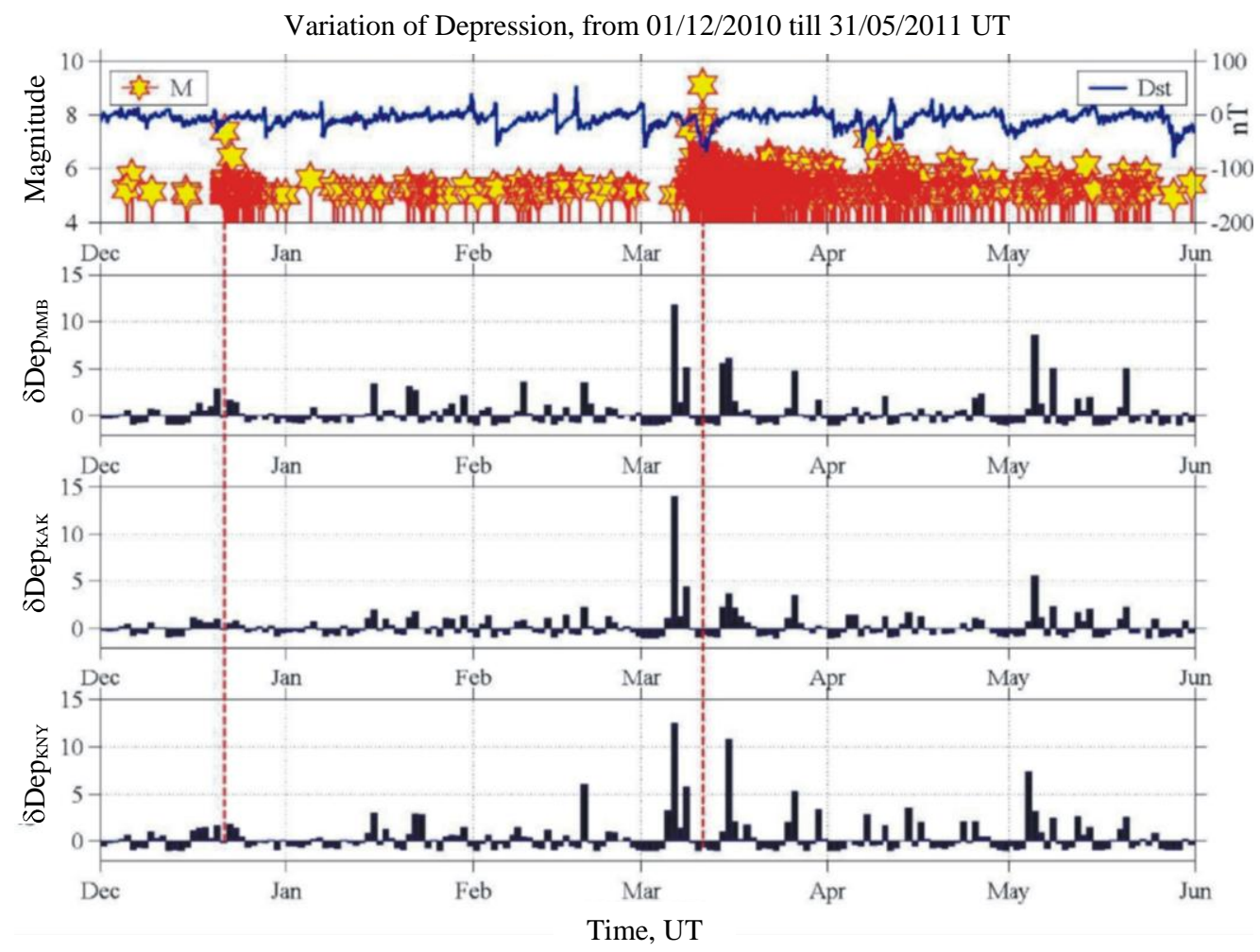

Fig. 2. Results of processing. Upper panel: Dst index of geomagnetic activity (blue line) and the occurrence of EQs with $M_{w}>5$. A yellow star means one EQ, and its corresponding magnitude is given by its height. The 2nd, 3rd and 4th panels refer to the temporal evolutions of $\delta D e p_{\mathrm{MMM}}, \delta D e p_{\mathrm{KAK}}$ and $\delta D e p_{\mathrm{KNY}}$ at three Japanese stations. Two vertical red dashed lines indicate the times of EQs occurred on December 21, 2010 and on March 11, 2011 (our main target) 
Temporal evolution of depression at three Japanese observatories, $\delta D e p_{\mathrm{MMB}}, \delta D e p_{\mathrm{KAK}}$, and $\delta D e p_{\mathrm{KNY}}$ are shown from the second to the fourth panels (as a bar per day). The depression was calculated according to (2) in the frequency band of $0.03 \ldots 0.05 \mathrm{~Hz}(30 \ldots 50 \mathrm{mHz})$.

It is clear from the top panel of Fig. 2 (the occurrence of EQs) that the seismic activity was relatively low before March 9. That is: there were about 15 EQs with $M_{w}>5$ and only two EQs with $M_{w}>5.5$ in the region of our analysis during more than one month before March 9. The maximum values of depression ( $\delta$ Dep) reach the range from 2 to 6 at different stations. Then, we pay our special attention to a statistically significant and conspicuous peak on March 6, common to the three Japanese observatories in Fig. 2. The extreme value of $\delta D e p$ is found to exceed by several times all previous values at all observing sites. The March 6 date is 5 days prior the main shock of magnitude $M_{w}=9$ and 3 days ahead a strong foreshock with $M_{w}=7.5$. The maximum peak of $\delta$ Dep $(\approx 14)$ is observed at KAK in Fig. 2, which was the closest to the EQ epicenter. The corresponding values of $\delta D e p$ are about 12 or so at the other two stations MMB and KNY. When looking at variations in $\delta D e p$ at three stations, we observe that standard deviation of the $\delta D e p$ fluctuations before the EQ is smaller by a factor of 2-3 at Kakioka than at other two stations, probably reflecting the different electromagnetic environment. By taking the ratio of the peak value to the corresponding standard deviation at each station, we obtain that the peak in $\delta D e p$ at KAK observatory is much more informative than the observed value itself in Fig. 2. Especially, when compared with other stations (MMB, KNY). The largest value of $\delta D e p$ at KAK is reasonably acceptable in the context of its proximity to the EQ epicenter.

After March 6 with the most enhanced $\delta$ Dep, the amplitude of $\delta D e p$ decreases, see Fig. 2. Although, the seismic activity is still high throughout the time interval. The Dst (Disturbance storm time) index reflects the dynamics of magnetospheric ring current. Simultaneously, this current is one of the main sources of the global magnetic field variation. So, Dst is chosen as a reliable indicator of the geomagnetic activity at the low and middle latitudes. It seems to be no clear correlation of the $\delta D e p$ magnitude with the Dst index as seen in Fig. 2. Therefore, we can attribute the $\delta D e p$ peak on March 6 to the Japan EQ with $M_{w}=9$. On the other hand, an increase in $\delta D e p$ is seen in the vicinity of two separate strong seismic events. The first of them was a rather weak response observed in the vicinity of EQ $M_{w}=7.5$ occurred on December 21, 2010. It was detected during the period of a low background level of $\delta D e p$. The second one was observed before the
March swarm. So, it is reasonable to suggest that these were precursors of the two EQs. Small peaks are sometimes noticed in the subsequent interval after the main shock, e. g., March 15, March 28 or so. These are attributed to the aftershock activity.

Summary and Discussion. First of all, we summarize the observational facts on the depression of ULF horizontal (H) component possibly associated with the March 11 huge EQ in Japan.

(1) The depression of ULF horizontal $(\mathrm{H})$ magnetic field component of the magnetospheric origin was observed simultaneously at three Japanese stations (KAK, MMB and KNY) on March 6, 2011.

(2) The depression was found to be most pronounced at KAK, while the depression was also clearly detected at MMB and KNY (but to a less degree).

Characteristics of ULF depression in horizontal magnetic field component observed in possible association with the huge Japan EQ, seem to be consistent with the former statistical results [16]. The phenomenon itself was remarkable in the sense of a large peak in the depression. Probably it is explained by a close association with the huge EQ.

Here we discuss whether the peak in depression observed at Japanese observatories on March 6 is a possible precursor to the huge EQ on March 11. The EQ prediction requires answering the following three questions: (1) "When?", (2) "Where?", and (3) "How big?" We discuss these three points by making the full use of the above observational facts.

The question of the ULF anomaly time is the simplest one. By using the formal statistical information about ULF depression $[15,16]$ summarized also in [3], we state that an EQ will happen 1-5 days after the peak of $\delta D e p$, i. e., from 7 to 11 of March, and the most probable day is the 9 of March. As expected from the former results for moderate magnitude EQs, the first violent foreshock $\left(M_{w}=7.5\right)$ happened on March 9 and the main shock $\left(M_{w}=9\right)$ happened on March 11 .

The second question on the EQ location is more complicated because of high variability of spatial electromagnetic interferences and of the scale of the preparation zone. Owing to the first reason, detection of the ULF depression strongly depends on the local electromagnetic interference. This causes ambiguous estimates of the distance to the EQ epicenter based on the characteristics of depressions at different observatories. The great preparation area leads to the weak variation of depression at distances of about $2000 \mathrm{~km}$ (the distance between MMB and KNY is about $1900 \mathrm{~km}$ ). We can accept as a preliminary estimate that the EQ epicenter should be closer to KAK, because the peak of $\delta D e p$ there was higher than at two other observatories (MMB and 
KNY). A similar conclusion follows from the analysis of seismicity before the shock on March 6 . The maximum activity is seen at the North-East of KAK. After March 6 all the violent EQ events took place in the same region as seen in Fig. 1.

Now we have the last question concerning the magnitude of a forthcoming event. We have already mentioned that we cannot use the linear dependence of $\delta D e p$ on the density of the seismic energy release because of high interference leading to the saturation at the low magnitudes. However, an approximate linear relationship does exist between the value of $\delta D e p$ and EQ magnitude ([3, 16]), and we can state, based on the level of $M_{s}=5.5 \mathrm{EQs}$, that the expected magnitude will be essentially higher, probably larger than 7. More information can be extracted from the small difference in depression between three stations located at distances of almost two thousand $\mathrm{km}$. The expected magnitude for such a scale of preparation zone is in the range from 7 to 8 [18]. The similar estimate was attempted by means of the theoretical expectation on the EQ preparation zone size $[19,20]$. The ionospheric perturbations were estimated for some land EQs in Japan, by making full use of the data from multiple VLF/LF propagation paths. It was found that the experimental size of ionospheric perturbations ranges from $1 / 2$ to $1 / 3$ of the theoretical value [19]. By using this information, the experimental value in the present paper, $R_{o b}=1000 \mathrm{~km}$ and on the assumption of a circular shape of the ionospheric perturbation, the expected magnitude $(M)$ would be, at least, 7.3-7.7. This estimate seems to be consistent with the above estimate. These estimates proved to be realistic, although we do not know the real scale of the depression effect.

As for the generation mechanism of the ULF depression in magnetic field components, two hypotheses have already been proposed [3, 15, 16]. The first possibility is a decrease in the penetration coefficient of ULF fluctuations of the Alfven waves from the magnetosphere due to turbulent increase in the effective Pedersen conductivity of the ionosphere. The second hypothesis is a change in the wave number $(\mathrm{k})$ distribution of the source ionospheric turbulence. Whatever the hypothesis is more plausible (probably the 1st linear hypothesis is more acceptable), the depression in horizontal magnetic field components of magnetospheric ULF fluctuations apparently arises from the precursory ionospheric disturbances; that is, a kind of seismoionospheric effects.

We have found the clear depression on March 6. In accordance with this inference, we have already found that the lower ionosphere was perturbed on March 5 and 6. The conclusion was based on subionospheric VLF/LF propagation on the paths from the American NLK transmitter (Seattle USA) to Japanese VLF/LF stations (Chofu, Kasugai and Kochi) [21]. We have match evidence on the seismo-lower-ionospheric interaction detected in the subionospheric VLF/LF propagation. The lower ionosphere was really disturbed during these days, and this was not a coincidence, but in accord with the ULF depression.

Finally, there are many points in the present work that demand a further elaboration. These are: the detailed study of the spatial scale of the phenomenon; the kind of ionospheric perturbation; and its impact on the observed depression, etc.

The authors are grateful to Dr. N. Yagova for helpful advices. We also thank the staff of the World Data Center for Geomagnetism (WDC) for providing the data of magnetic fields. Also we are grateful to Advanced National Seismic System (ANSS) for providing us with the data of seismicity. One of the authors (MH) is grateful to Mayekawa Houonkai Foundation for its support.

\section{References}

1. Hayakawa M. Seismo-Electromagnetics: Lithosphere Atmosphere - Ionosphere Coupling / M. Hayakawa, O. A. Molchanov. - Tokyo: TERRAPUB, 2002. - 477p.

2. Pulinets $S$. A. Ionospheric Precursors of Earthquakes / S. A. Pulinets, K. Boyarchuk. - Berlin: Springer, 2004. - 215 p.

3. Molchanov O.A. Seismo Electromagnetics and Related Phenomena: History and latest results / O. A. Molchanov, M. Hayakawa. - Tokyo: TERRAPUB, 2008. - 189 p.

4. A statistical study on the correlation between lower ionospheric perturbations as seen by subionospheric VLF/LF propagation and earthquakes / M. Hayakawa, Y. Kasahara, T. Nakamura et al. // J. Geophys. Res. - 2010. - $\underline{115}$. A09305 (9 p.).

5. Hayakawa M. Monitoring of ULF (ultra-low-frequency) geomagnetic variations associated with earthquakes / M. Hayakawa, K. Hattori, K. Ohta // Sensors. - 2007. - $\underline{7}$, N 7. - P. 1108-1122.

6. Fraser-Smith A. C. The ultra-low-frequency magnetic fields associated with and preceding earthquakes // Electromagnetic Phenomena Associated with Earthquakes / A. C. FraserSmith; ed. by M. Hayakawa. - Trivandrum (India): Transworld Research Network, 2009. - P. 1-20.

7. Kopytenko Yu. A. Study of local anomalies of ULF magnetic disturbances before strong earthquakes and magnetic fields induced by tsunami // Electromagnetic Phenomena Associated with Earthquakes / Yu. A. Kopytenko, V. S. Ismaguilov, and L. V. Nikitina; ed. by M. Hayakawa. - Trivandrum (India): Transworld Research Network, 2009. - P. 21-40.

8. Discovering of ultra-low-frequency emissions connected with Spitak earthquake and his aftershock activity on data of geomagnetic pulsations observations at Dusheti and Vardzija / Yu. A. Kopytenko, T. G. Matiashvily, P. M. Voronov et al. IZMIRAN, 1990. - 27 p. - (Preprint N 3a (888)).

9. Results of ULF magnetic field measurements near the epicenters of the Spitak $(M=6.9)$ and the Loma-Prieta $(M=7.1) \quad$ earthquakes: Comparative analysis / O. A. Molchanov, Yu. A. Kopytenko, P. M. Voronov et al. //, Geophys. Res. Lett. - 1992. - 19, N 14. - P. 1495-1498.

10. Low-frequency magnetic field measurements near the epicenter of the $M_{s}$ 7.1 Loma Prieta earthquake / A. C. FraserSmith, A. Bernardy, P. R. McGill et al. // Geophys. Res. Lett. 1990. - 17, N 9. - P. 1465-1468. 
11. Results of ultra-low-frequency magnetic field measurements during the Guam earthquake of 8 August 1993 / M. Hayakawa, R. Kawate, O. A. Molchanov, and K. Yumoto // Geophys. Res. Lett. - 1996. - 23, N 3. - P. 241-244.

12. Hattori $K$. ULF geomagnetic changes associated with large earthquakes / K. Hattori // Terr. Atmos. Ocean. Sci. - 2004. 15, N 3. - P. 329-360.

13. Campbell W. H. Natural magnetic disturbance fields, not precursors, preceding the Loma Prieta earthquake / W. H. Campbell // J. Geophys. Res. - 2009. - 114. - A05307 (7 p.).

14. Masci $F$. On the seismogenic increase of the ratio of the ULF geomagnetic field components / F. Masci // Phys. Earth Planet. Interiors. - 2011. - 187, N 1-2. - P. 19-32.

15. Preseismic ULF electromagnetic effect from observation at Kamchatka / O. A. Molchanov, A. Yu. Schekotov, E. N. Fedorov et al. // Natural Hazards Earth Syst. Sci. - 2003. - 3. - P. 1-7.

16. Seismo-ionospheric depression of the ULF geomagnetic fluctuations at Kamchatka and Japan / A. Schekotov, O. Molchanov, K. Hattori et al. // Phys. Chem. Earth. - 2006. 31. - P. 313-318.

17. Console $R$. Testing earthquake forecast hypotheses / R. Console // Tectonophys. - 2001. - 338, N 3. - P. 261-268.

18. Morgounov V.A. Slip weakning, strain and short-term preseismic disturbances / V. A. Morgounov // Ann. Geophysics. - 2004. - 47, N 1. - P. 133-149.

19. DobrovolskyI. R. Estimation of the size of earthquake preparation / I. R. Dobrovolsky, S. I. Zubkov, V. I. Myachkin // Pageoph. - 1979. - 117. - P. 1025-1044.

20. Yamauchi T. Subionospheric VLF/LF monitoring of ionospheric perturbations for the 2004 Mid-Niigata earthquake and their structure and dynamics / T. Yamauchi, S. Maekawa, T. Horie et al. // J. Atmos. Solar-terr. Phys. 2007. -69 , iss. 7. - P. 793-802.

21. A possible precursor to the 20113.11 Japan earthquake: Ionospheric perturbations as seen by subionospheric VLF/LF propagation / M. Hayakawa, Y. Hobara, Y. Yasuda et al. // Ann. Geophysics. - 2012. - $\underline{55}$, special iss. - P. 95-99.

Manuscript received July 13, 2012.

А. Щекотов, Е. Федоров, Я. Хобара, М. Хаякава

\section{ДЕПРЕССИЯ УНЧ-КОЛЕБАНИЙ ГЕОМАГНИТНОГО ПОЛЯ КАК ВОЗМОЖНЫЙ ПРЕДВЕСТНИК ЯПОНСКОГО ЗЕМЛЕТРЯСЕНИЯ 11 МАРТА 2011 Г.}

Рассматриваются электромагнитные предвестники землетрясений; на различных расстояниях от эпицентра сильнейшего землетрясения в Японии 11 марта 2011 г. исследуется депрессия (уменьшение амплитуды) УНЧ-вариаций геомагнитного поля, вызванная магнитосферными источниками. Используются записи флюксгейт-магнетометров, расположенных от эпицентра на расстояниях $\sim 300$ и 1300 км. Интервал наблюдений относится к периоду с 1 декабря 2010 г. по 31 мая 2011 г. Обнаружено резкое снижение УНЧ-колебаний геомагнитного поля в диапазоне частот $0,03 \ldots 0,05$ Гц $(30 \ldots 50$ мГц) во всех японских обсерваториях (Какиока, Мамабетсу и Канойя). Эффект наблюдался за 3 дня до форшока магнитудой $M=7,5$ и за 5 дней до главного толчка магнитудой $M=9$. Максимальная депрессия в несколько раз превысила те, которые наблюдались ранее, причем в ближайшей к эпицентру обсерватории (Какиока) эффект был наибольшим. Таким образом, депрессию можно рассматривать как предвестника гигантского землетрясения в Японии 11 марта 2011 г.

Ключевые слова: землетрясения, кратковременные предвестники, депрессия УНЧ-колебаний геомагнитного поля, сейсмоионосферная депрессия, сейсмоэлектромагнетизм.

О. Щекотов, Е. Федоров, Я. Хобара, М. Хаякава

ДЕПРЕСІЯ УНЧ-КОЛИВАНЬ
ГЕОМАГНТТНОГО ПОЛЯ
ЯК МОЖЛИВИЙ ПРОВІСНИК
ЯПОНСЬКОГО ЗЕМЛЕТРУСУ 11 БЕРЕЗНЯ 2011 P.

Розглядаються електромагнітні провісники землетрусів; на різних відстанях від епіцентру сильного землетрусу в Японії 11 березня 2011 досліджується депресія (зменшення амплітуди) УНЧ-варіацій геомагнітного поля, що спричинена магнітосферними джерелами. Використовуються записи флюксгейт-магнетометрів, розташованих від епіцентру на відстанях $\sim 300$ і $\sim 1300$ км. Інтервал спостережень відноситься до періоду з 1 грудня 2010 р. по 31 травня 2011 р. Виявлено різке зниження УНЧ-коливань геомагнітного поля в діапазоні частот $0,03 \ldots 0,05$ Гц $(30 \ldots 50 \mathrm{мГц)} \mathrm{у} \mathrm{всіх} \mathrm{японських}$ обсерваторіях (Какіока, Мамабетсу i Канойя). Ефект спостерігали за 3 дні до форшоку магнітудою $M=7,5$ і за 5 днів до головного поштовху магнітудою $M=9$. Максимальна депресія в кілька разів перевищила ті, що спостерігалися раніше, причому в найближчій до епіцентру обсерваторії (Какіока) ефект був найбільшим. Таким чином, депресію можна розглядати як провісника гігантського землетрусу в Японії 11 березня 2011 р.

Ключові слова: землетруси, короткочасні провісники, депресія УНЧ-коливань геомагнітного поля, сейсмоіоносферна депресія, сейсмоелектромагнетизм. 